\title{
The Presence of Vari - Kirou Pira Unit at Panion Hill (SE ATTICA, GREECE)
}

\author{
Bassi E.K., Soukis K. and Lekkas S. \\ Department of Dynamic Tectonics and Applied Geology, School of Geology, National and \\ Kapodistrian University of Athens, 15784,Athens, ekbassi@geol.voa.gr, soukis@geol.uoa.gr, \\ slekkas@geol.uoa.gr
}

\begin{abstract}
Detailed mapping in the area of Panion Hill (SE Attica, Greece), revealed the existence of three metamorphosed lithological units which are separated by major tectonic contacts. The lower unit is located at the western part of Panion Hill and comprises marble - schist alternations that pass transitionally to massive dolomitic marbles of probable Triassic age. The intermediate unit comprises exclusively massive to thick bedded marbles that occupy the central and eastern part of the hill. The upper unit can be observed mainly at the foothills of Panion and comprises HP/LT schists, exhibiting greenschsist facies retrograde metamorphism. The contact between the lower and the intermediate unit is a low-angle normal fault, dipping to the east-southeast whereas the upper unit, in most cases is juxtaposed against the intermediate and lower units by high angle normal faults. These contacts accommodated the exhumation of the lowermost metamorphic formations of Attica at least in the last stages. The overall structure resembles that of Mt. Hymittos (east of Athens), where the Vari Schists and Dolomitic Marble formations (Vari - Kirou Pira Unit, VKPU) underlie tectonically the Lower Marble, Kesariani Schists and Upper Marble formations (Hymittos Unit, HU). Based on lithological and structural similarities the lower unit of Panion Hill is considered to be part of the Vari - Kirou Pira Unit and the intermediate unit part of the Hymittos Unit, respectively. The upper unit of Panion Hill belongs to the allochthonous Lavrion Unit. The existence of a major tectonic contact separating formations of VKPU and HU in several outcrops in SE Attica signifies that it is of no local character. Furthermore, it supports the suggestion of dividing the relatively autochthonous unit of Attica into two distinct units: the upper Hymittos Unit and the lower Vari - Kirou Pira Unit, the latter standing for the actual autochthonous unit of SE Attica.
\end{abstract}

\section{INTRODUCTION}

This paper is concerned with the geological structure of Panion Hill (SE Attica, Greece), which is considered a typical example of SE Attica geology.

Although during the past years many researches were carried out on the geological structure of Attica, there has been no consensus regarding the geotectonic setting of Attica units. For practical reasons most researchers still use the lithostratigraphic column of the relative autochthonous unit of Attica given by Lepsius (1893) and revised by Marinos \& Petrascheck (1956). Despite the different opinions expressed most researchers (Kober 1929, Marinos \& Petrascheck 1956, Papanikolaou 1986, Katsikatsos 1990 etc) accept that SE Attica consists of two metamorphosed alpine units: the underlying autochthonous Attica Unit and the overlying allochthonous Lavrion Unit.

The allochthonous Lavrion Unit shows HP/LT relict minerals and comprises phyllites with crystalline limestone intercalations and blocks of ophilolitic rocks (Marinos \& Petrascheck 1956). According to Papanikolaou (1986) this unit represents an upper Cretaceous mélange. The stratigraphic column of the relative autochthonous unit of Attica, as suggested by Lepsius (1893), consists of the following formations, from base to top: Vari Schists, Pirnari Dolomites, Lower Marble, Kessariani Schists, and Upper Marble. Based on fossils found in different places in Attica, their age is considered to be Mesozoic. 
Recently expressed views suggest further subdivision of the two Attica Units. According to Lekkas \& Lozios (2000), the relative autochthonous Attica Unit can be divided into two units: the Vari Kirou Pira Unit, which includes Vari Schists and Pirnari Dolomites, and the Hymittos Unit, which includes Lower Marble, Kessariani Schists and Upper Marble. These authors reported that in Mt Hymittos all Hymittos Unit formations are tectonically juxtaposed against all Vari - Kirou Pira formations and they proposed that the latter represents the relative autochthonous unit of Attica.

Photiades \& Carras (2002) suggested a new stratigraphic column for Lavreotiki area (SE Attica) in which they distinguished three units. The lower Autochthonous Unit consists of Triasic - Jurassic Pelagonian series, a disconformity related to the Eohellenic orogenic phase and a Tithonian Lower Cretaceous non-metamorphic transgressive cover. Upon the lower unit lies the Phyllite nappe (intermediate unit) which comprises phyllites that have undergone blueschists facies metamorphism during the Eocene and retrograde greenschists facies metamorphism during the Oligocene - Miocene. The Upper Unit is a non-metamorphic Pelagonian nappe consisting of upper Cretaceous limestones and ophiclitic rocks.

The study of Panion Hill is important because it reveals the existence of an important tectonic contact within the relative autochthonous Attica Unit that has also been described in Mt. Hymittos (Lekkas \& Lozios, 2000). Information about the relatively autochthonous Attica Unit, derived from detailed mapping of Panion in addition with data and observations from other places (Mt. Hymittos. Lombarda, etc) supplement and support the recently expressed subdivision of the relative autochthonous unit and thus lead to a revision of the geological structure and evolution of SE Attica.

\section{DESCRIPTION OF THE LITHOLOGICAL UNITS}

Panion Hill is located in SE Attica and is built mainly by metamorphic alpine formations. This area is situated at the northwestern part of the Atticocycladic metamorphic core complex and according to Durr et al. (1978) and Papanikolaou (1986) it belongs to the median tectonometamorphic belt. Lepsius (1893) concluded that lithologies cropping out at Panion Hill correspond to different formations of the relative autochthonous stratigraphic column whereas Marinos \& Petrascheck (1956) suggested that all different lithologies belong to the Lower Marble formation.

Panion Hill is constructed by three metamorphosed lithological units, separated by two major tectonic contacts (Fig. 1). The lower unit (western Panion) comprises marble - schist alternations and dolomitic marbles; the intermediate unit (central and eastern Panion) comprises massive to thick bedded marbles; the upper unit (mainly at the foothills of Panion) comprises phyllites with few crystalline limestone intercalations and blocks of ophiolitic rocks.

The western part of Panion Hill is occupied by the basal formation of the lower lithological unit which comprises marble - schist alternations. This composite formation includes white to grey-blue impure platy marbles and micaceous chloritic and calcitic schists which often enclose horizons of metamorphosed basic igneous rocks of various thicknesses. These horizons are related to volcanic activity synchronous to sedimentation, as indicated by the fact that they are folded along with the marble and schist alternations (Fig. 2). Synmetamorphic deformation resulted in NE-SW trending isoclinal folds. Due to this folding overall formation thickness can reach up to a few hundred meters.

At the stratigraphically upper part of the basal formation the impure marble horizons gradually give place to horizons of gray - white dolomitic marble. This part of the marble - schist alternations is characterized by Lepsius (1893) as dolomitic calc schists and can be seen at the southern slope of Panion Hill where it signifies the transition to massive dolomitic marble (Fig. 3) which constitutes the top formation of the lower lithological unit (Pirnari Dolomites by Lepsius 1893). The lower part of this dolomitic marble comprises gray to darc-colored dolomites with small intercalations of impure marbles and can be observed at the northern slope of Panion Hill and at Heloni Hill, whereas the upper part comprises massive white dolomites. The alpine age of this formation is proved by Marinos \& Petrascheck (1956) who reported brachiopodes (possibly Terebratula sp.) and algae (Makroporella sp.) in these dolomites and also by Negris (1915-1919) who reported corals of probable Triassic age. 


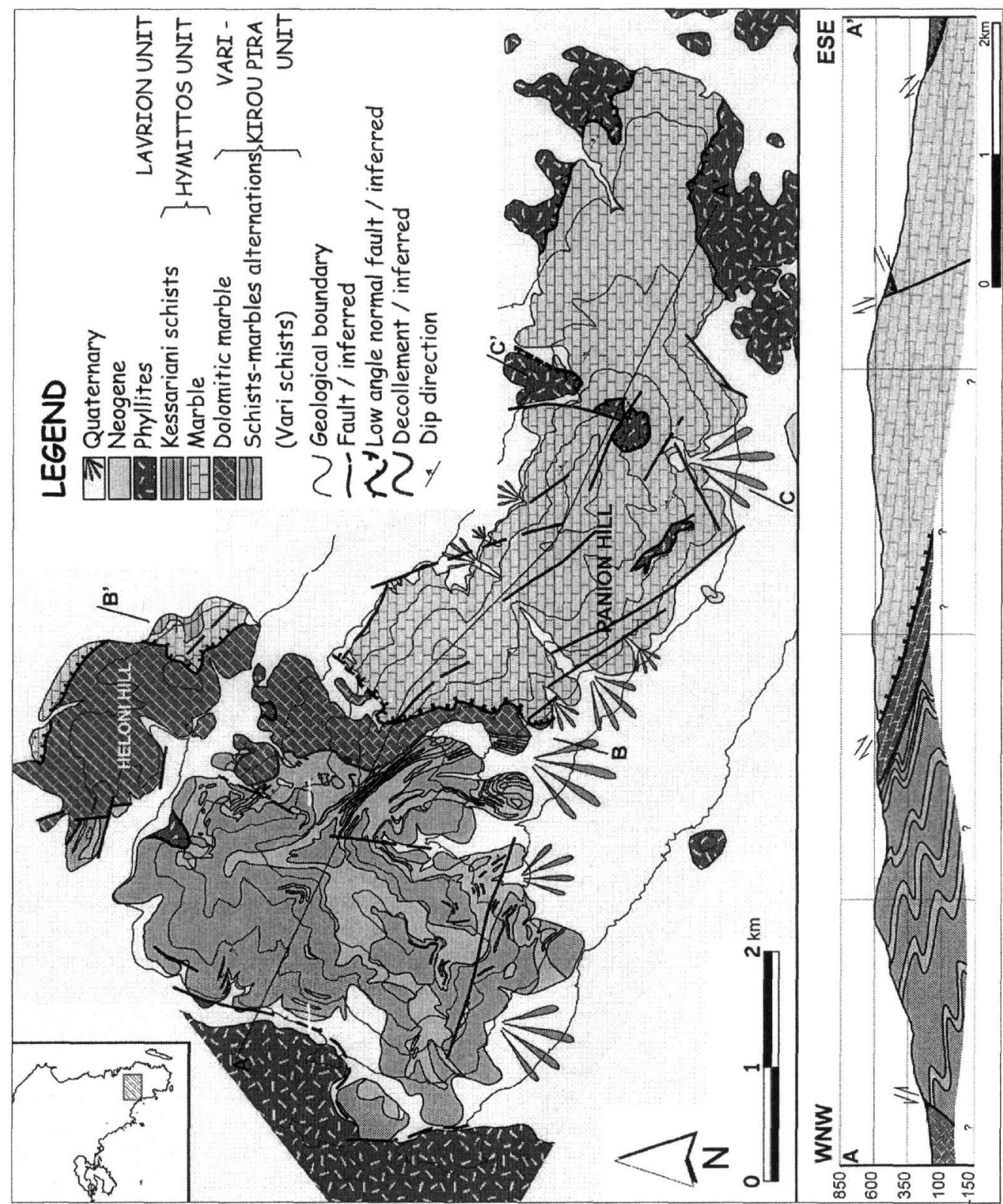

Figure 1. Geological map of Panion Hill (SE Attica) and cross section AA', displaying the succession of the three units.

The dolomitic marbles overlie the schist and marble alternations with an east-northeast dipping tectonic contact that has the characteristics of a décollement. As a result, the uppermost white dolomitic horizons rest directly on the transitional beds of the southern slope, whereas, at the northern slope and at Heloni Hill the marble and schist alternations underlie tectonically the lower darc-colored dolomitic horizons. 


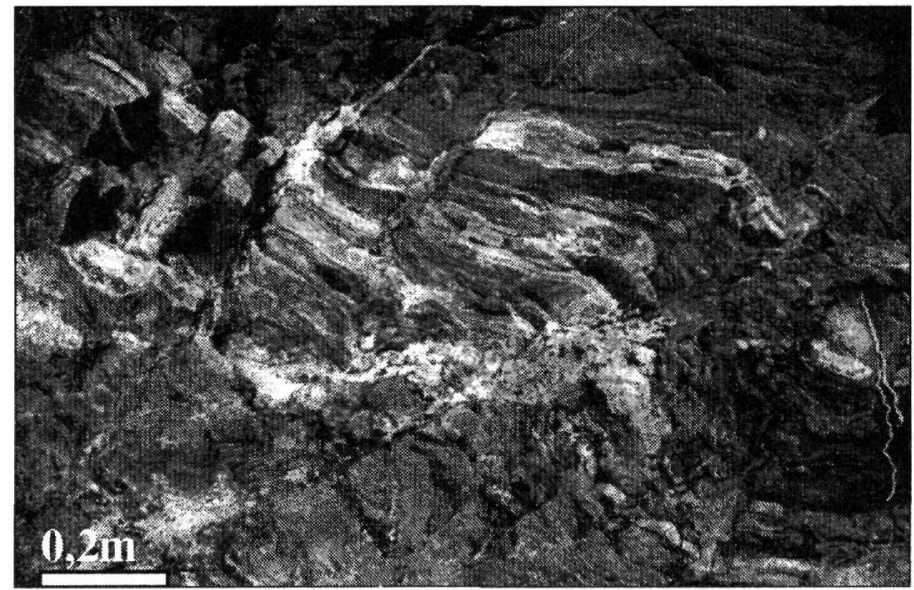

Figure 2. Metamorphosed basic igneous rocks, folded along with the marble and schist alternations of the lower lithological unit.

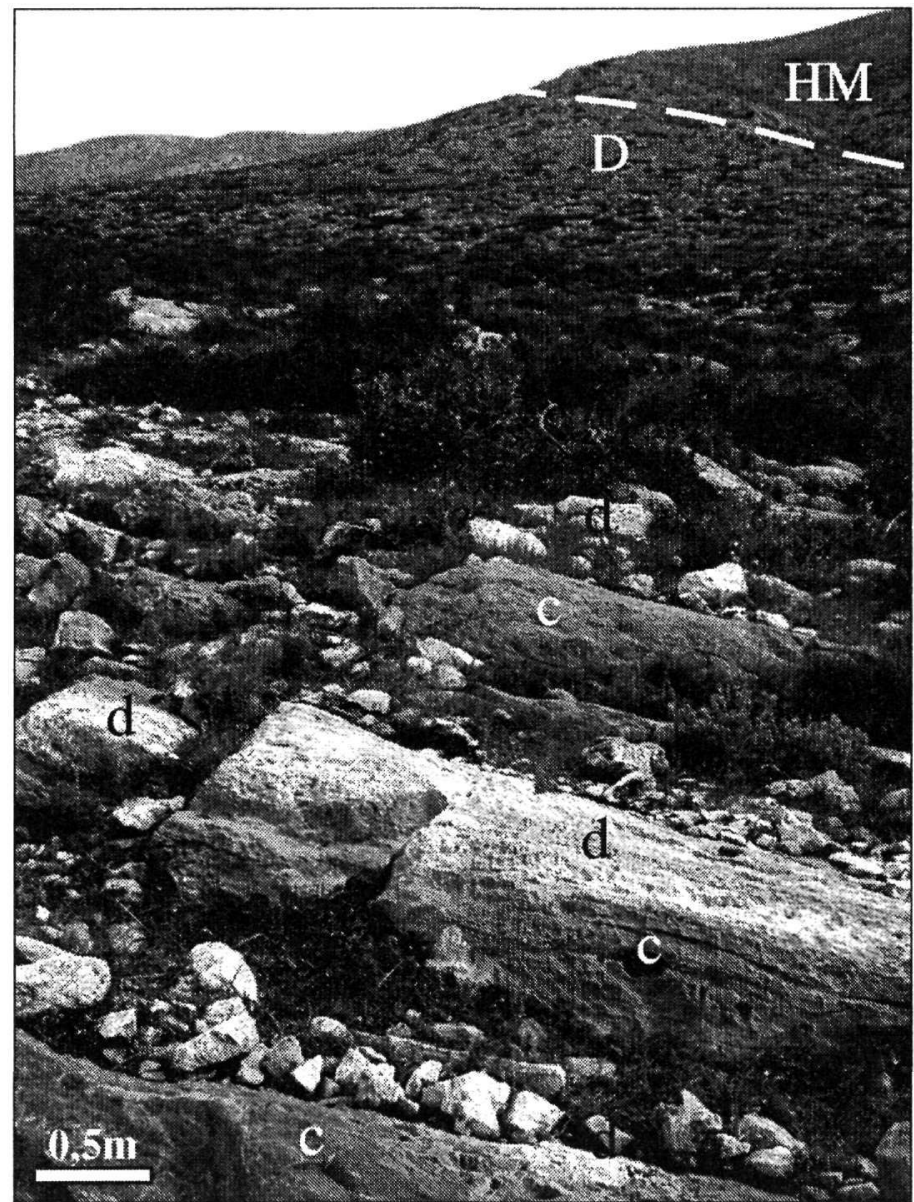

Figure 3. Alternations of light-colored dolomitic and dark grey-colored calcitic beds signifying the transition from the schist-marble formation to the dolomitic marble (d: dolomitic beds, c: calcitic beds, D: Dolomitic Marble, HM: intermediate unit Marble). 


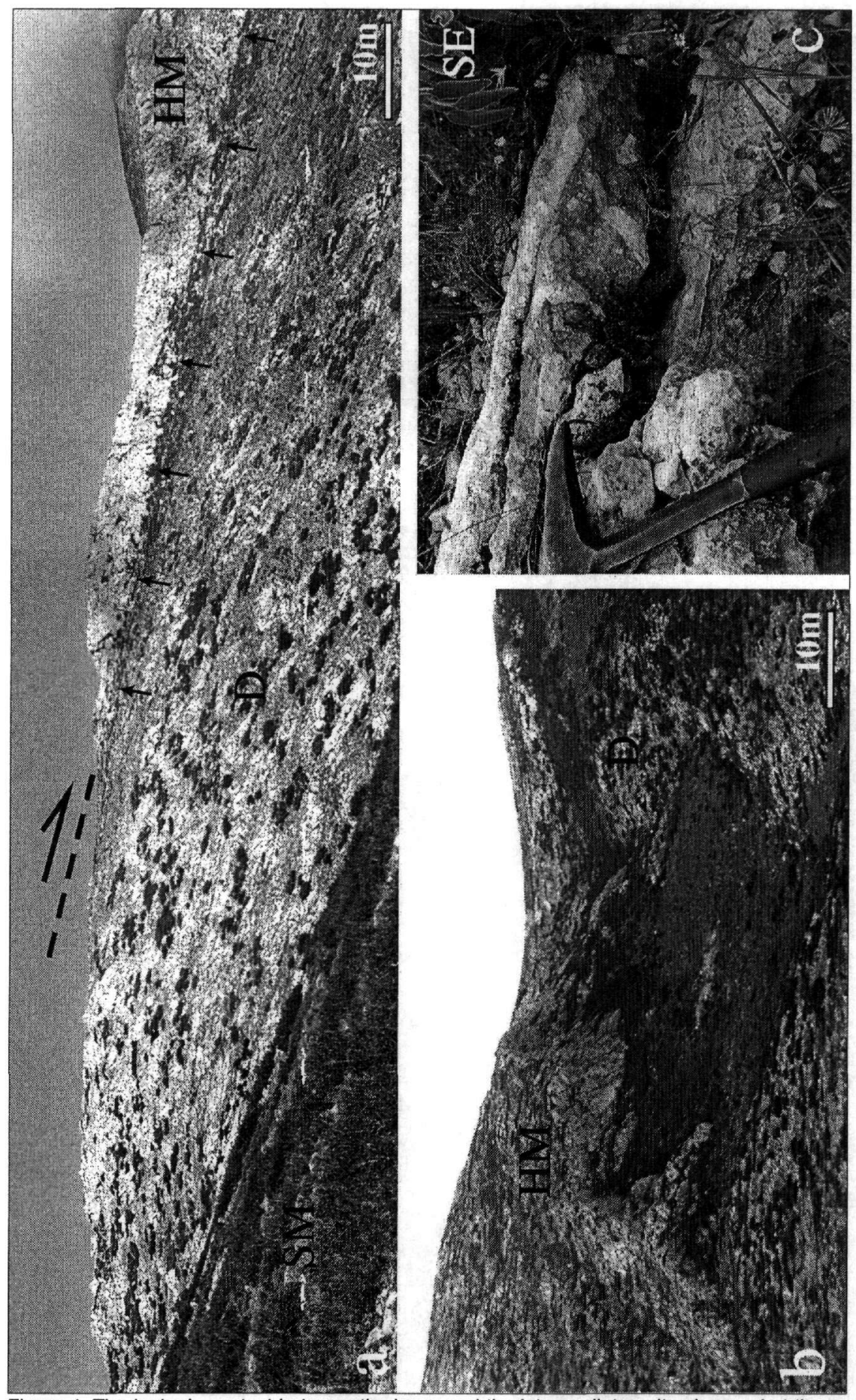

Figure 4. The tectonic contact between the lower and the intermediate units observed at the southern slope (a) and the northern slope (b). A few meters thick cohesive unfoliated to slightly foliated cataclastic rock is observed along the contact. Rotated clasts (c) indicate top to SE sense of movement (SM: schist-marbles alternations, D: Dolomitic Marble, HM: intermediate unit Marble). 
The central part of Panion Hill is occupied by massive to thick-bedded gray to reddish marbles which at the eastern part give place to medium-bedded white-gray marbles with occasional dark films, possibly suggesting a transition to the overlying Kessariani schists. At this area the marble is often brecciated, ankeritised and cut by iron solutions' veins, which signifies the contact with the eroded overlying phyllites. Me.rbles of the intermediate unit also appear at Heloni Hill where a probable outcrop of Kessariani schists can be seen resting on top of them. These marbles correspond to the Lower Marble of Lepsius (1893) and overlie tectonically the dolomitic marbles.

The overall thickness of the formation reaches up to a few hundred meters. In places axial plane schistosity can be observed, dipping generally to the northeast. Also, both lower and intermediate units' formations exhibit northeast plunging mineral extension lineation.

The contact between the lower and the intermediate lithological unit can be observed at the central part of Panion Hill. It is a generally east-dipping undulated low-angle normal fault that crosscuts Panion and can be observed at Heloni Hill and at both the northern and southern slopes of Panion Hill, where it forms a characteristic scarp due to the difference between the readily eroding underlying dolomite and the more competent overlying marble (Fig. 4a,b). At the northern slope it dips to the east-northeast and at the southern to the southeast (Fig. 5) and it is characterized by the existence of a cohesive unfoliated to slightly foliated $2-5 \mathrm{~m}$ thick cataclasite. In some places rotated clasts indicate top to SE sense of movement (Fig. 4c). The dolomitic marble is intensely brecciated underneath the contact and bears south to southeast-plunging striations.

The upper unit appears mainly at the foothills of Panion Hill and is constituted by schists and phyllites with intercalations of white to gray crystalline limestones and small blocks of ultrabasic rocks. Also, small klippe occur in several places upon the hill, overlying both the marble - schist alternations of the lower and the marbles of the intermediate unit (eastern Panion). Marinos \& Petrascheck (1956) correlate all these outcrops to the allochthonous Lavrion Unit. The contact with the underlying units can be observed mainly at the northern slopes and at the top of Panion Hill (Fig. 6). It is a low-angle undulated tectonic contact, dipping towards northeast and northwest and it is often accompanied by upper structural level cataclasites. Kinematic indicators formed in the ductile deformation regime are symmetric and they do not indicate any preferred sense of movement. However, cataclastic surfaces along the contact are dipping towards NE and NW. At the southeastern and western slopes the upper unit is juxtaposed against the intermediate unit and lower unit respectively by high angle normal faults that truncated the low-angle contacts. This configuration can be clearly seen at the central-eastern part of Panion crest (Fig. 7).

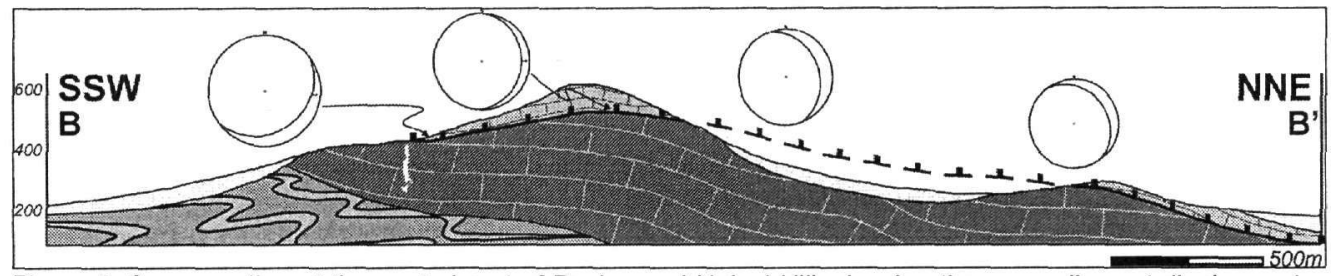

Figure 5. Cross-section at the central part of Panion and Heloni Hill, showing the generally east-dipping undulated low angle normal fault that separates the lower from the intermediate unit.

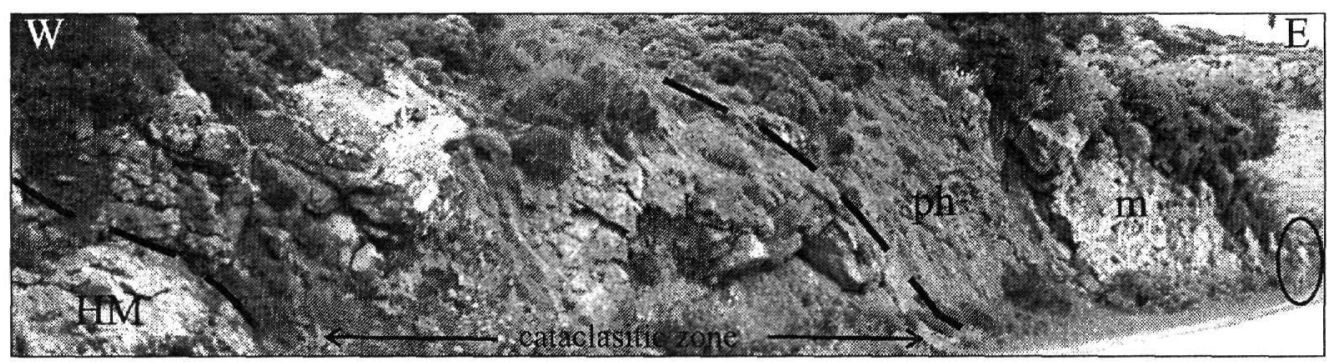

Figure 6. Phyllites (ph) and marble intercalations of the upper unit overlying tectonically the marbles of the intermediate unit (HM) at the north zastern slope of Panion Hill. A several meters thick cataclastic zone, comprising brecciated marbles of the intermediate unit, is observed along the contact. Human figure for scale. 


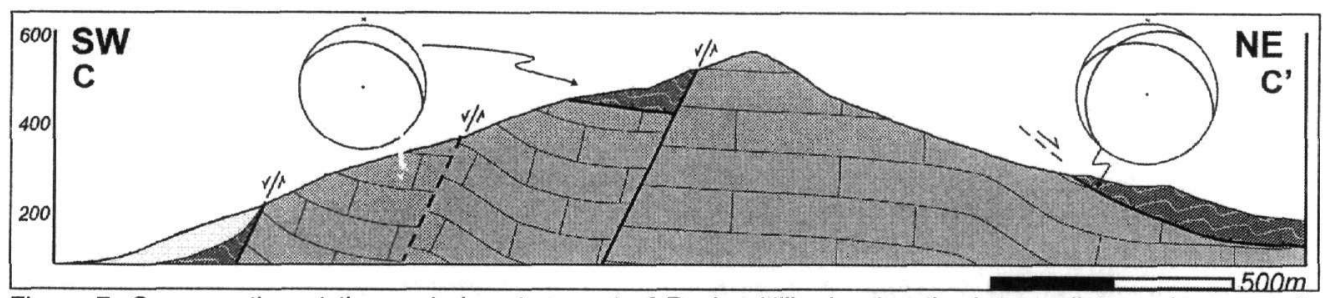

Figure 7. Cross-section at the central-eastern part of Panion Hill, showing the intermediate and upper unit, separated by low- and high-angle normal faults.

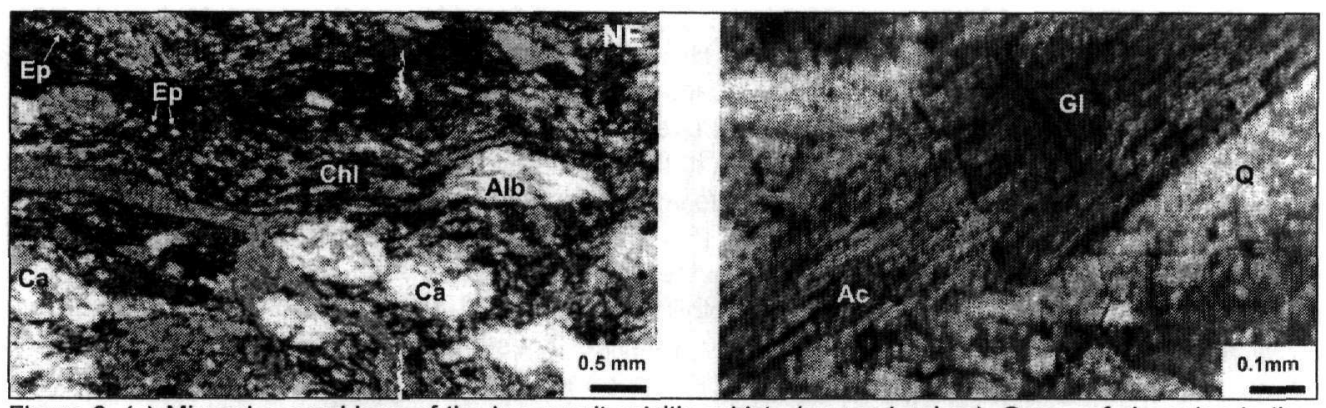

Figure 8. (a) Mineral assemblage of the lower unit calcitic schists (crossed polars). Sense of shear top-to-theNE (b) Glaucophane replaced by actinolite in the upper unit schists (crossed polars). (Alb: Albite, Ca: calcite, Chl: chlorite, Ep: Epidote, Gl: glaucophane, Ac: actinolite, Q: quartz).

The lower and intermediate units show greenschist facies minerals (Fig. 8a) whereas the upper unit shows HP/LT minerals (mainly glaucophane) retrograded to greenschist facies minerals (actinolite Fig. 8b). Typical mineral assemblage for the calc schists of the lower unit includes calcite + chlorite + epidote \pm quartz \pm albite + opaque and for the metabasic rocks albite + chlorite + epidote \pm quartz + opaque.

\section{DISCUSSION}

Lepsius' (1893) work on Attica geology was outstanding for its time though questions rose when tested in the field. Problems were inherited among other reasons by the fact that he assigned the dolomitic marbles in some cases to the Upper Marble (Northern Mt. Hymittos) in other cases to the Lower Marble (Mt. Olymbos SE Attica) or most of the times to the individual formation of Pirnari Dolomites. Marinos \& Petrascheck (1956) have contributed a great deal in assigning the SE Attica alpine formations into the relatively autochthonous Attica Unit and the allochthonous Lavrion Unit. However, by unifying the three lower formations of the Attica stratigraphic column given by Lepsius (1893) questions concerning the statigraphy of the autochthonous unit were not solved. On the contrary, this unification suppressed the importance of the dolomitic marbles and above all it veiled the existence of a significant tectonic contact within the stratigraphic column of SE Attica. This major tectonic contact is observed in Lombarda (Alexopoulos et al 1998), Hymittos Mt. (Lekkas \& Lozios 2000), and in Panion Hill (this paper) where it juxtaposes the formations of the lower lithological unit against the intermediate unit.

The stratigraphic column of Panion Hill comprises three distinct lithological units separated by two major tectonic contacts (Fig. 9). It is noteworthy that transitional phases are observed among the formations of the lower unit and also among the formations of the intermediate unit, whereas no indication of transition exists between these two units. The structure resembles that of Hymittos Mt. as described by Lekkas \& Lozios (2000), therefore we concluded in the following correlation:

- The upper unit of Panion Hill is part of the allochthonous Lavrion Unit (LU).

- The intermediate unit can be correlated to the Hymittos Unit (HU) and specifically to the Lower Marble formation. 
- The lower unit is correlated to the Vari - Kirou Pira Unit (VKPU).

Vari - Kirou Pira Unit includes the marble - schist alternations (Vari Schists) and the massive dolomitic marbles (Pirnari Dolomites) cropping out in several places in SE Attica. Pirnari Dolomites is a key formation to the geolc gical structure of SE Attica for the following reasons: i) based on what Lekkas \& Lozios (2000) reported for Hymittos Mt. and on our own observations throughout SE Attica we believe that many of the Triassic fossil-bearing outcrops reported in the literature could be related to the dolomitic marbles, ii) the Triassic age of the dolomites suggests a partly Triassic age for the underlying Vari Schists. Taking also into account the presence of the metabasic rocks, Vari Schists can be very well related to the Lower to Middle Triassic volcanosedimentary formations known in several units of the non-metamorphosed Hellenides, iii) marble-schist alternations appear in different horizons of the SE Attica stratigraphic column whereas extended massive dolomitic marbles belong to the lowernıost lithological unit, iv) dolomitic marbles are tectonically overlain by formations belonging to Hymiios Unit or Lavrion Unit and together with the Vari Schists they represent the lowermost formations in SE Attica.

After the recognition of detachments and low-angle normal faults the nature of the tectonic contacts at the northwestern part of the Atticocycladic metamorphic core complex (SE Attica and SE Evia, Andros and Tinos Islands) is amatter of debate. According to some authors the exhumation of the metamorphosed units took place in a back-arc setting during which several detachments and low-angle normal faults were formed (Gautier \& Brun 1994a, b, Gautier 2000 and references there in). According to others the tractonic contacts that juxtapose the overlying HP/LT units against the underlying LP units are thrus! faults formed during the burial of the alpine units, and consequently, synorogenic processes accommodated the exhumation of these HP units (Avigad \& Garfunkel 1989, 1993, Avigad et al. 1997, 2000 Shaked et al. 2000 and references there in).

The contact between the lower Vari-Kirou Pira Unit and the intermediate Hymittos Unit is a major tectonic contact of no local character, since it is observed at several locations throughout SE Attica (Lombarda, Alexopoulos et al 1998, Hymittos Mt., Lekkas \& Lozios 2000). In Panion Hill it caused the relative uplift of the underlying lower lithological unit in respect to the intermediate. It exhibits upper structural level cataclastic rocks, indicating activity at least during the last stages of the exhumation processes that brought the metamorphosed units on surface. The décollement observed in Panion Hill between the two formations of the lower VKPU is not related with large scale movements, as indicated by the transition at the southern slope, although it must have participated to the uplift process.

The contact between the upper Lavrion Unit and intermediate Hymittos Unit had immediately drawn the attention of geologists who had characterized it as an overthrust. In Panion Hill Lavrion unit is juxtaposed against the underlying units mostly by high-angle normal faults. The few cases where the contact is a low-angle fault don't provide unequivocal kinematic indicators or other data in order to determine whethe ${ }^{-}$it is a thrust or a normal fault. However, at the northwestern part of Panion Hill (see Fig 1) a smail Lavrion Unit clippe is tectonically emplaced on top of the lowermost Vari Schists formation, thus omitting Hymittos Unit and the Pirnari Dolomites. This could be attributed to gravitational sliding and not necessarily to some low-angle normal fault activity. Alexopoulos et al (1998) report the existence of a probable molasssic Upper Eocene - Lower Oligocene nonmetamorphic clastic sequence in SE Attica, tectonically wedged between the overlying by Lavrion Unit and the underlying Hymittos Unit. According to these authors the juxtaposition of Lavrion Unit against the probable molassic formation took place before Late Miocene, indicating that lateorogenic extensional tectonism affected metamorphosed and non metamorphic SE Attica formations. Based on our observations in Panion area, we conclude that in this area this contact represents a low-angle normal fault that caused the sliding of Lavrion Unit generally towards the NE.

The above unit succession, as well as the tectonic contacts bounding these units, are seen at several locations and represent the typical structure of SE Attica. This structure has basically resulted from the activity of the two low-angle faults bounding the intermediate Hymittos Unit and secondarily from the later high-angle faults that disrupted them (Fig. 10).

The presence of VKPU at Panion Hill as well as in Hymitos Mt has major implications on the stratigraphic column of SE Attica. The VKPU - HU contact is a major low-angle normal fault that can be traced in an area extended from Mt. Hymittos (east of Athens) up to Panion Hill, therefore it should be included in the construction of the stratigraphic column of SE Attica. Based on its exis- 
tence and the fact that Vari schists and the dolomitic marbles (Pirnari Dolomites) are always found below this contact, we suggest that the relative autochthonous unit of Attica should be divided into two distinct units: the overlying Hymittos Unit and the underlying Vari - Kirou Pira Unit which represents the actual relative autochthonous unit of SE Attica.

Triassic dolomitic marbles below blueschists formations and separated from them by a lowangle fault have been reported in Tinos Island (Melidonis 1980, Avigad \& Garfunkel 1989, 1993, Gautier \& Brunn 1994a,b), which is also a part of the Atticocycladic metamorphic core complex. Yet, there is not enough evidence to correlate them with the SE Attica dolomitic marbles.

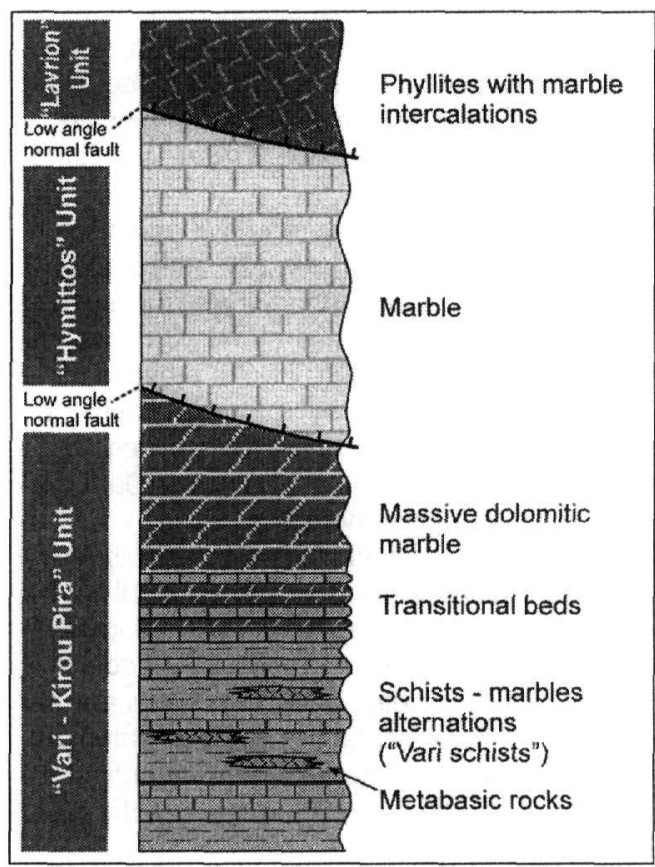

Figure 9. Stratigraphic column of Panion Hill and correlation with the units of Hymittos Mt proposed by Lekkas \& Lozios (2000).

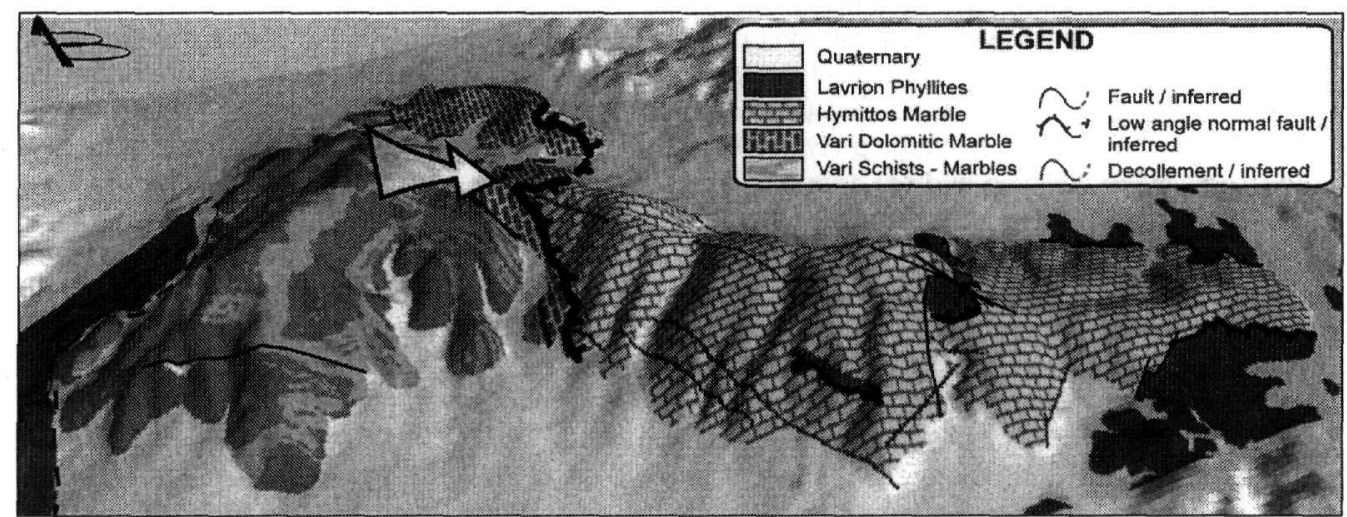

Figure 10. 3D shaded relief overlaid by geology, highlighting the low angle normal fault that has caused the movement of the intermediate Hymittos Unit towards ENE. The arrow indicates the generally eastward sense of movement in Panion area. 


\section{CONCLUSIONS}

The geological structure of the studied area comprises three lithological units separated by two low-angle faults and it is similar to the structure of Mt. Hymittos as described by Lekkas \& Lozios (2000):

- The lower unit of partly Triassic age corresponds to Vari-Kirou Pira Unit

- The intermediate unit of Mesozoic age corresponds to Hymittos Unit

- The upper unit shows HP/LT minerals retrograded to greenschists facies minerals and corresponds to Lavrion Unit

The above succession of units represents the geological structure of SE Attica. The presence of Vari-Kirou Pira Unit in Panio: Hill as the lowermost lithological unit as well as the existence of a major low-angle normal fault separating this unit from the overlying formations indicate that the relative autochthonous unit of Attica should be divided into two subunits: the overlying Hymittos Unit and the underlying Vari - Kirou Pira Unit, the latter standing for the relative autochthonous unit of SE Attica.

\section{REFERENCES}

Alexopoulos A., Lekkas S. \& Mor aiti E. 1998. On the occurrence of a non metamorphic Upper Eocene - Lower Oligocene clastic sequence, wedged between the allochthon and the relatively autochthon system of Attika (Greece) Bull. Geol. Soc. Greece, 32/1, 79-84 (in Greek with English abstract).

Avigad, D. and Garfunkel, Z. 1989. Low-angle faults above and below a blueschist belt - Tinos Island, Cyclades, Greece. Terra Nova 1, 182-187.

Avigad, D. and Garfunkel, Z. 1993. The role of extension in unroofing the cycladic blueschist belt. Bull. Geol. Soc. Greece, XXVIII, 57-69.

Avigad, D., Garfunkel, Z., Jolivet, L. \& Azanon, J. M. 1997. Back-arc extension and denudation of Mediterranean eclogites. Tectonics $16,924-41$.

Avigad, D., Garfunkel, Z., Jolivei L. \& Azanon, J. M. 2000. Reply on "Back-arc extension and denudation of Mediterranean eclogites". Tectonics 19, 410-414.

Dürr, ST., Altherr, R., Keller, J. Okrusch, M. Seidel, E.1978. The median Aegean crystalline belt: Stratigraphy, Structure, Metamorphism, Magmatism. In Alps, Apennines, Hellenides, 455-477.

Gautier P. 2000. Comment on "Back-arc extension and denudation of Mediterranean eclogites" Tectonics 19, 406-409.

Gautier P. \& Brun, J.P. 1994a. Ductile crust exhumation and extensional detachments in the central Aegean (Cyclades and Evvia islands), Geodin. Acta 7 57-85.

Gautier, P. \& Brun, J.P. 1994b. C.rustal-scale geometry and kinematics of late-orogenic extension in the central Aegean (Cyclades and Evvia Island). Tectonophysics, 238, 399-424.

Katsikatsos, G. 1990. Geology of Greece, Athens, 451p. (In Greek).

Lekkas, S. \& Lozios, S. 2000. Tectonic structure of Mt. Hymittos. Ann. Geol. Pays Hell. 38, 47-62.

Lepsius, R., 1893. Geologie von Attica. Ein Beitrag zur Lehre von Metamorphismus der Gesteine, Berlin Zeitschr. f. partkt. Geol., 4, 196 S.592 p.

Marinos, G. \& Petrascheck, W. 1956. Laurium. I.G.M.E. Geol. Geoph. Res., V/1, 247pp.

Melidonis, N. G. 1980. The geological structure and mineral deposits of Tinos island (Cyclades, Greece). The Geology of Greece, 13, 0-80. Inst. Geol. Min. Exp., Athens.

Negris, Ph., 1915-1919. Rôches cristallophylliennes et tectonique de la Grèce. Ref. Pia: N. Jah. F. Min. Geol. Pal. Beil., I, 100p.

Papanikolaou D. 1986. Geology of Greece, Eptalofos publications 240p. (In Greek). 